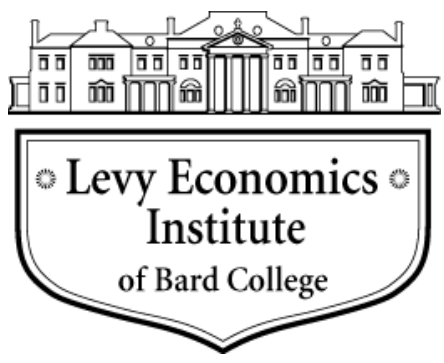

Working Paper No. 972

\title{
In the Long Run We Are All Herd: On the Nature and Outcomes of the Beauty Contest
}

\author{
by \\ Lorenzo Esposito \\ Bank of Italy and \\ Catholic University of the Sacred Heart, Milan \\ and \\ Giuseppe Mastromatteo \\ Catholic University of the Sacred Heart, Milan
}

September 2020

The Levy Economics Institute Working Paper Collection presents research in progress by Levy Institute scholars and conference participants. The purpose of the series is to disseminate ideas to and elicit comments from academics and professionals.

Levy Economics Institute of Bard College, founded in 1986, is a nonprofit, nonpartisan, independently funded research organization devoted to public service. Through scholarship and economic research it generates viable, effective public policy responses to important economic problems that profoundly affect the quality of life in the United States and abroad.

\author{
Levy Economics Institute \\ P.O. Box 5000 \\ Annandale-on-Hudson, NY 12504-5000 \\ http://www.levyinstitute.org
}

Copyright (C) Levy Economics Institute 2020 All rights reserved

ISSN 1547-366X 


\begin{abstract}
Since the 2008 crisis, the economics literature has shown a renewed interest in Keynes's “beauty contest" (BC) as a fundamental aspect of the functioning of financial markets. We argue that to understand the importance of the $\mathrm{BC}$, psychological and informational factors are of small importance, and a dynamic-structural approach should be followed instead: the BC framework is paramount because it is rooted in the historical trajectory of capitalism and it is not simply a consequence of "irrational" (i.e., biased) agents. In this genuine form, the BC mechanism allows one to understand the main trends of a financialized world. Moreover, the conventional nature of financial markets provides a sound method for assessing different economic policies whose effectiveness depends on how much they can influence the convention itself. This alternative understanding of the $\mathrm{BC}$ can be used to start the needed rethinking of economics, urged by the crisis, that is for now reduced to studying the financial and psychological "imperfections" of the market.
\end{abstract}

KEYWORDS: Financial Crisis; Financialization; Behavioral Economics; Herd Behavior; Convention

JEL CLASSIFICATIONS: B15; E12; G01; G40 


\section{INTRODUCTION}

"I made a mistake.” (Greenspan 2008)

After the 2008 crisis, "John Maynard Keynes resurfaces in the media" (Dequech 2011), together with other typical outcasts like Hyman Minsky and Charles Kindleberger. The financial collapse was strong enough to suggest a rethinking of how markets work. In general, alternative understandings tended to gravitate toward the behavioral economics (BE) framework, especially in the field of finance. The discussion also touched the Keynesian notion of the beauty contest (BC) as one of the basic herd behaviors of financial markets (Cespa and Xives 2015; Thaler 2015). Even before these events, different strands of economic theory acknowledged that herd behavior is important for understanding modern finance (Scharfstein and Stein 1990). All these analyses of the $\mathrm{BC}$ went easily along with psychological explanations because, just like the $\mathrm{BE}$ framework, they do not include any particular historical dynamics or institutional features: it happens to be how investors behave and the $\mathrm{BC}$ is explained using psychological or even biological aspects (for instance Bikhchandani, Hirshleifer, and Welch [1992]), but not historical trends, with the study of "institutional shifts" as a very rare exception (Dunn 2003). We will try to explain that, on the contrary, the BC's paramount importance lies in the fact that it is where the financial system is historically directed: the point is the structural development of the markets, not some biological legacy in investors' mind.

The fact that the dynamic aspect of the $\mathrm{BC}$ is largely ignored was also helped by the mixed way Keynes discussed it in the General Theory. Sometimes, psychological factors are introduced as parts of human nature - for instance, he speaks about "instability due to the characteristic of human nature" and of "spontaneous optimism" (Keynes ([1936] 2018, 141)—but Keynes also introduced the $\mathrm{BC}$ describing the development of capitalism from a situation of free competition, "when enterprises were mainly owned by those who undertook them," to one based on large corporations, where investments were decided as part of a complex financial strategy becoming more and more similar to financial assets (and they tended to become public companies). In this way, corporate strategies were more and more decided by managers recruited by shareholders (in practice, by institutional investors). Managers tended to follow the pack to avoid being singled out in case of failure. The separation of ownership and management evolves into financial markets dominated by institutional investors determining the $\mathrm{BC}$. 
In this dynamic understanding, the $\mathrm{BC}$ can be connected to the fundamental aspects of modern capitalism: absentee ownership and concentration of capital, financialization and the role of money manager capitalism (as envisaged by Minsky), inequality, and secular stagnation. The dynamic interpretation of the $\mathrm{BC}$ also allows for an effective assessment of the viability of different economic policies. In fact, this is the most powerful tool for grasping their effectiveness. It also allows the discarding of psychological explanations of market dynamics, as they are not particularly relevant.

The paper is organized as follows. We start by analyzing the connection between uncertainty and conventions, as they are connected to the dynamic nature of the BC. Secondly, we deepen the different conceptions of conventional behavior and Keynes's analysis of it with respect to financial markets. Thirdly, we touch on the links between convention and Rudolf Hilferding's institutional analysis of capitalist development. Then we explain why the BE examination of conventional behavior is not useful in finance. Finally, we analyze the consequences of a BCruled world, especially as far as systemic risk and postcrisis policies are concerned.

\section{UNCERTAINTY AND CONVENTIONS}

In Keynes's theory, the role of conventions is essential to understanding how the market works. Keynes introduced the role of conventions by explaining that investors use them to reduce the radical uncertainty surrounding investment decisions. This aspect has been extensively acknowledged in the ensuing literature (for instance, Rossi [1996]); on the contrary, the association between conventional behaviors and the process of capital concentration and progressive separation between ownership and management analyzed by Keynes, Joseph Schumpeter, and others has been neglected. We discuss them in turn to show their necessary connection.

What is the origin of the uncertainty? Although in Keynes and afterwards it is discussed in different contexts, the most interesting is when it is seen not as caused by the static distribution of information among agents (as in the information asymmetries models) but by innovation (Dequech 2006). A Schumpeterian entrepreneur risks unchartered waters to revive profitability: "the central dimension that organizes innovation... is uncertainty" (Kline and Rosenberg 2009). 
The entrepreneur is forced to innovate by competition and the results of innovation cannot be assimilated to a lottery, because costs, rewards, and chances have yet to be created: it is impossible to measure the extent of our ignorance about something that does not exist yet (Dequech 1999); in fact, as Elster $(1983,119)$ points out: "innovations are not responses to preexisting needs, since they often create the very need they satisfy." How will the new product (or process) change the market? How will the incumbents react? How will relative prices change? This is the knowledge investors need: uncertainty is uncertainty on the reactions to innovation. To quote again Kline and Rosenberg (2009): "the greater the change introduced, the greater the uncertainty not only about technical performance but also about market response." All in all, innovation and uncertainty are both a vital strong point of capitalist development and a major source of its instability.

The most common strategy used by firms to tame uncertainty is growth. Ceteris paribus, a bigger firm can better resist competition and innovation. Industrial and financial concentration have long been studied as the strategic response to competition (Marris 1964, 1998) and historical evidence confirms that, in any sector, concentration goes from low to high but, since the bigger a firm is the more catastrophic it is for its management to make a mistake, uncertainty not only produces but is also produced by concentration. Top managers in charge of large corporations are interested in the survival of their firms. Profit maximization is important and drives their strategies, but avoiding catastrophic events is normally even more important (Berg 2015), and this yields herd behavior. As Keynes ([1936] 2018, 138) put it: "Worldly wisdom teaches that it is better for reputation to fail conventionally than to succeed unconventionally." Uncertainty induces concentration, concentration induces conventional behaviors, and hence uncertainty brings about the BC. In an organizational context, conventions are linked to routines, informal corporate culture, and many other aspects that allow firms to survive and prosper. This is how psychology originally dealt with economics issues in Herbert A. Simon, Richard M. Cyert, and others. Once again, without a connection between economic trends and conventions, the link between conventional behaviors and organizations is lost and nonrational behavior is considered only the outcome of psychological features. 


\title{
3. THE BC'S DYNAMIC NATURE
}

If the $\mathrm{BC}$ is analyzed as one of the main results of capitalist development, its growing importance can be detected. The starting point of this historical analysis is the separation of ownership and management of the means of production due to the growth of firms' size. Keynes outlined this trend well before the General Theory. For instance, in The End of the Laissez-Faire ([1926] 2012), he points out:

\begin{abstract}
One of the most interesting and unnoticed developments of recent decades has been the tendency of big enterprise to socialise itself. A point arrives in the growth of a big institution... at which the owners of the capital, i.e., its shareholders, are almost entirely dissociated from the management, with the result that the direct personal interest of the latter in the making of great profit becomes quite secondary. When this stage is reached, the general stability and reputation of the institution are the more considered by the management than the maximum of profit for the shareholders. The shareholders must be satisfied by conventionally adequate dividends.
\end{abstract}

It is interesting to observe that Keynes makes use of the term "conventionally adequate" to define a reasonable return on investment. It is also interesting that Keynes talked of "shareholders," which can be intended as private investors (as it was the case normally in Keynes's analysis) but can be more generally interpreted as the controllers of the company. When Keynes wrote these words, many social scientists were trying to make sense of the rise of giant corporations. It is sufficient to cite books like The Modern Corporation and Private Property (Berle and Means 1932) and, more oriented toward political issues, The Managerial Revolution (Burnham [1941]1972) to remind one of the wide scientific production on the issue. ${ }^{1}$ This kind of institutional analysis continued after the war (for instance, Galbraith [1967] and Chandler [1977]). In the chapter 12 of the General Theory, Keynes ([1936] 2018, 131) introduces the historical issue as follows: "In former times, when enterprises were mainly owned by those who undertook them or by their friends and associates, investment depended on a sufficient supply of individuals of sanguine temperament and constructive impulses who embarked on business as a way of life, not really relying on a precise calculation of prospective profit."

\footnotetext{
${ }^{1}$ Reflections on this issue were already present well before Keynes, for instance in Adam Smith, who observed: "The directors of such [joint-stock] companies, however, being the managers rather of other people's money than of their own, it cannot well be expected, that they should watch over it with the same anxious vigilance with which the partners in a private copartnery frequently watch over their own" (as quoted in Jensen and Meckling [1976]). Observations on this issue are also present in Karl Marx (for example, in the material used to compose the third volume of Capital). Needless to say, the issue grew in importance from Smith's to Marx's and then to Keynes's time.
} 
Things changed with the development of big firms: "With the separation between ownership and management which prevails to-day and with the development of organized investment markets, a new factor of great importance has entered in, which sometimes facilitates investment but sometimes adds greatly to the instability of the system. In the absence of security markets, there is no object in frequently attempting to revalue an investment to which we are committed. But the Stock Exchange revalues many investments every day and the revaluations give a frequent opportunity to the individual (though not to the community as a whole) to revise his commitments" (Keynes [1936] 2018, 132; our emphasis).

The separation implies that the capital markets have a key influence on investment and hence on business cycles that originate from investment waves. Capital markets allow for greater funding of firms, thus facilitating investment, but they also increase instability by inducing a continuous reassessment of asset value based on herd behavior, thus also inducing "short-termism," which is a major component of financialization (Whalen 2017). This entails, for instance, the collapse of the average holding period for stocks (Lukasz and Smith 2015). Already in 1990, James Crotty observed: "To exaggerate only slightly, there are no long-term stockholders anymore." This is especially true where institutional investors are stronger, as in United Kingdom and the United States (Davies et al. 2014), but advanced economies are all progressively dominated by institutional investors (OECD 2017). Given that professional investors are keener to follow conventions than owners of a single firm and that the bulk of financing is nowadays decided by professional investors, conventions are more and more vital to understanding economic reality.

The rising importance of the $\mathrm{BC}$ - " "a fundamental change in the structure and dynamic of capitalism" (Palley 2013) — is linked to economic and financial concentration and to the separation of ownership and management. These developments reduce the differences among sectors and firms because their top management often changes, making firms' strategies, behaviors, and business models more similar and reduced diversity among firms. The rush to have the best CEOs, paid with stock options, in its turn magnified short-termism in corporate strategies (Pasinetti 2009). This "fundamental change" also entails a recomposition of firms' assets and costs. In giant corporations, fixed costs are so important that if corporations are not

\footnotetext{
2 "Short-termism" is when agents weigh near-term outcomes too heavily at the expense of longer-term opportunities, thus depressing future investment projects and potential output (Davies et al. 2014).
} 
able to sell as much as planned, they risk bankruptcy. The size of a firm and the weight of its fixed costs become so overwhelming that the top management only look for stability: "career managers preferred policies that favored the long-term stability and growth" (Chandler 1977, 10). In a big corporation, "strategic inertia" is paramount because changing is a costly and uncertain process (Crotty 1993). The bigger the firm, the stronger the threat posed by instability and uncertainty is and hence the need for stability by means of conventions. Short-termism and inertia could seem at odds one another, but conventions are precisely what makes them meet. Following the conventions allows top managers to forget about the future so that they can be both short-termist and mired in inertia.

Secondly, the more a firm's size grows, the more convention passes through into organizational behaviors (Simon 1947; Orléan 2004); from being a largely informal, individual behavior, it becomes a set of rules that creates a specific corporate culture necessary for managing a big company, because the personal expertise of the owner cannot do it anymore. This organizational element is lost in the neoclassical theory, apart from specific contexts (Tirole 1988). As Joseph Stiglitz (1985) observed, "conventional theory treats the typical firm in an anthropomorphic manner," as if General Motors was run like a small shop (Marris and Mueller 1980), while we live in a "world in which the motives of organization members seemed not to fit the standard textbook mold" (Galbraith 1967, vii). This is not redressed by the BE critics of neoclassical theory, who only look at individual cognitive biases as if a giant industrial or financial conglomerate had a brain that can be fooled by the trompe l'oeil effects they use to explain the markets.

In an organizational framework, a convention is a way to cope with the ruling corporate culture, and management is prone to rely on it because it is less risky. Inside the organization, there is a social pressure to conform (Dequech 2003) and deviations are punished (Orléan 2004). The contradictory point in analyzing the link between innovation and conventions is that for a manager or an investor to be unconventional is a dangerous strategy because it means acting against the market (or the organization) and it is better attempted where there are no other options on the table. But this no-option situation inevitably arises. The wise investor/manager follows the convention and jumps to the next wave just in time. Or, at least they try. 


\section{WHAT IS A CONVENTION?}

We explained why conventions tend to dominate business strategies. Now we take a deeper look into their nature, which is such a widely debated topic that it has its own discipline (Young 1996; Orléan 2004). We can define a convention as "a socially shared informal pattern of behaviour and/or thought" (Dequech 2006). It follows then that a convention is socially shared, (i.e., it is a widespread attitude), and the more widespread, the more convenient it is to follow. This is what happens with market standards. From an individual point of view, imitation behavior-Orléan's (2014) "mimetic hypothesis" - makes sense. It is convenient to follow the convention because others are following it, so its success is a self-fulfilling dynamic. But, more importantly, it is a social effect: market standards arise as a consequence of competition among agents during the innovation process. Because of the network economies, a standard tends to dominate the entire market irrespective of its technical efficiency. ${ }^{3}$ This means that a convention is mostly arbitrary inasmuch as it is not intrinsically superior to other behaviors, but it is just what others are doing. Like market standards, conventions can result in suboptimal results and yet it is wise to adhere to them as long as they rule the market (Favereau 2013). Moreover, many modern technologies "display increasing returns to adoption" (Arthur 1989), making network economies stronger than ever (UNCTAD 2017).

The second core aspect of a convention is that it is normally informal. It is neither an official rule nor does it need formal sanctions to be enforced. Its followers can even be unaware of it. External pressures (such as laws, sanctions, etc.) can increase its appeal but convention exists also without them: investors will stick to it because others do the same.

The last aspect we touch on is the operational role of a convention. In front of mounting competition, investors and entrepreneurs do not know and they cannot know what will happen, but they must act because waiting is not an option. The convention allows an agent to act in a situation of radical uncertainty. Uncertainty is costly and the cost is an increasing function of both the investment and the firm. Two possible institutional solutions are at hand: the trustification of the economy (i.e., the strong concentration of industries into vertically integrated

\footnotetext{
${ }^{3}$ They arise when a product's utility increases with the number of other agents consuming the good (Katz and Shapiro 1985).
} 
groups) and the convention of liquid markets. We will describe both these solutions, explaining why they converge in modern capitalism.

We have seen that conventions are the result of radical uncertainty surrounding the innovation process and that they are informal and difficult to define, as they are basically a market trend. These specific trends operate inside a general pattern known as the "projective convention" (Dequech 2011). If there are no reasons to change an idea, the present situation is projected onto the future. In a sense, this is close to the informational efficiency hypothesis of mainstream finance theory: present prices embed all relevant information and therefore, with no news, they will also prevail in the future. As Keynes points out in his 1937 article: "We assume that the existing state of opinion as expressed in prices and the character of existing output is based on a correct summing up of future prospects."

In practice, it is not always straightforward to identify what a convention is, and divergent opinions are possible. However, for all these difficulties, specific configurations of the market are clearly detectable, although different agents employ them differently. For instance, before 2008, banks were increasingly using the "originate-to-distribute" model, that is, wholesale funding based on the securitization of asset-backed securities. Even if this market trend prevailed, not every bank was completely fooled by the subprime fad.

If this is its nature, we can ask what a convention change means. For instance, when everybody is buying a particular asset class, if its price starts to sink, does it mean that the convention is over? Indeed, prices are also the most direct expression of the convention (and of a financial bubble) in Keynes's analysis. Price movements show that the convention is changing and, when the change becomes noticeable, the new projective convention will be that prices are declining, at least for the time being. Every investor tries to buy low and sell high and then proceeds to the next fad but, of course, only a few can "outwit the crowd," to use Keynes's expression. This behavior is unconventional as far as the first mover is concerned: a smart investor simply anticipates the other investors. As Keynes observed in the Treatise on Money: "The speculator tries to 'act in the same way' as the crowd (i.e., to follow the average opinion) 'a short time ahead"' (quoted in Dequech 2011). They are temporarily unconventional, planning to be conventional tomorrow, for instance, buying or selling an asset before the market does the same, but it is not good for the speculator to remain unconventional, as Keynes ([1936] 2018, 138) 
suggested: "If he is successful, that will only confirm the general belief in his rashness; and if in the short run he is unsuccessful, which is very likely, he will not receive much mercy." Understanding when it is appropriate to jump from a projective situation to the next is not unconventional per se, but only clever. So, it is correct to point out that "innovative behavior is at least in part unconventional" (Dequech 2003), but only in the sense of the specific fad that is followed, not the general pattern of how investors behave, which is always projective convention. Schumpeterian entrepreneurs, with the help of bank credit, break the $n$ convention to push the markets toward the $n+1$.

As we observed, Keynes's ideas on conventions also have historical-dynamic aspects, while the other most common theories have only a static nature (Mackenzie and Millo 2003). For instance, some scholars affirm that "the beliefs of market participants are self-fulfilling" (Farmer 2009) and that they have an "independent influence on economic activity" (Farmer 2010). Other economists analyze what happens if we reasonably assume that investors do not have structural knowledge of the economy and therefore "the forecast of others is crucial information used to forecast endogenous variables" (Kurz and Motolese 2010). Moreover, in a world of strong uncertainty, heterogeneous beliefs are the norm (Kurz 1994, 2008). These developments are interesting but they concentrate on finding a mathematical representation of the process (for instance, using Bayesian learning processes, as in Chamley [2002, ch. 1]), while the convention is not based on any calculus, but on institutional dynamics.

As Keynes observed: "our existing knowledge does not provide a sufficient basis for a calculated mathematical expectation" ([1936] 2018, 137). Investors do not have sufficient information to calculate a statistical distribution of the possible outcomes; therefore, it is more effective for them to simply project the convention into the future. Secondly, these theories are limited to informational aspects, while Keynes's (and Schumpeter's) uncertainty is more structural and dynamic, being linked to innovation. Other authors rely on the game theory framework (Stenfors 2014), which is a useful paradigm for explaining how informal coordination among agents comes about, but it is limited by the fact that it only conceives well-defined behavior ex ante, while innovation's uncertainty does not have predefined answers. We need more complex explanations of conventions that in Keynes are "qualitatively different" from the game theory conventions (Latsis, de Larquier, and Besis 2010). 


\section{THE CONVENTIONAL BEHAVIOR IN KEYNES}

Convention, according to Keynes, is a mental construct from which investors' behavior flows. In his works we can find a number of psychological hints. It is sufficient to think that the importance that the animal spirits embodied in the General Theory confirm this point, although they are not a thoroughly psychology-based explanation of the markets, as in the BE approach. Since Keynes never explicitly defined a convention, a variety of interpretations of this idea have developed. ${ }^{4}$ It is interesting to discuss the sources of Keynes's ideas because they can shed a light on how conventions operate. We will rapidly touch on these sources: George E. Moore, David Hume, and Henry Poincaré. As for Moore's ethics, his refusal of naturalism is important: "good" is a given state of affairs that is a conventional judgement (Lawson 2003). Moreover, Moore proposed an idea of "good" as not clearly defined (intuitionism), just like Keynes's conventions (Davis and Hands 2003; SEP 2015). Secondly, Keynes borrows from the Humean position that conclusions reached by induction (included statistical induction) are uncertain, and observations per se (included statistical analysis) cannot reduce this uncertainty (Meeks 2003; Roncaglia 2009). This means, inter alia, that no matter the precision of a statistical tool, it is extremely risky to put too much confidence in it. This also means that we know that, eventually, the ruling convention will cease to help us, just like the sun will cease to warm the Earth, but for the time being it is inevitable to act as if it will never happen.

The third source of inspiration was Poincaré, whose methodological conventionalism was a reaction to important scientific discoveries, especially in mathematics. Facing the non-Euclidian geometries, scientists reassessed their ideas of reality. Is Euclidian geometry the only truth, while the others are human inventions? In practice, new geometries are needed in specific mathematical fields where they are the reality, whatever it means. Therefore, Poincaré reaches the conclusion that one geometry is as good as any another and an experiment cannot decide between Euclid's and Lobacevskij's $(1905,85)$. In Poincaré, conventions have an arbitrary aspect but are rational nonetheless, just like a market standard. However, his thought "has been seriously neglected" in the literature on Keynes's conventions (Boylan and O'Gorman 2013) also because it is difficult to connect mathematical conventionalism to Keynes's mathematical ideas as exposed in the Treatise on Probability and elsewhere (Davidson 1991). Keynes's conclusions

\footnotetext{
${ }^{4}$ For an analysis of the different interpretations, see Mizuhara (2003) and Dequech (2011).
} 
can also be found in authors like Thorsten Veblen and they have been developed after him, in different conceptual frameworks, by Simon and other scholars (Brette, Lazaric, and Vieira da Silva 2017). Veblen and Simon are particularly relevant because they connect the role of habits and institutions to rational and strategic behavior inside the organizations, which, as we suggested, is the way to make sense of the BC in a financialized world.

Taken all together these sources point to a convention that is a self-fulfilling imitation based on arbitrary and transitory assumptions, and on the idea that others are better informed, therefore the "average opinion" is superior to our own. It is important to observe that with "average" we cannot understand a statistical result (as, for instance, the arithmetic mean of price distribution) but the prevailing mood of the market, something that is very difficult to formalize.

\section{THE ROLE OF CONVENTIONS ON FINANCIAL MARKETS}

We have seen that uncertainty stems from innovation. Now, innovation, in the context of financial markets can be basically understood as investment, i.e., trading financial assets. Therefore, if innovation means uncertainty, by the same token, investing in financial assets is an uncertain business. The role of innovation implies that there are no bases for a rational calculation of asset allocation. In the 1937 article for the Quarterly Journal of Economics, Keynes wrote to his General Theory critics observing: "Knowing that our own individual judgment is worthless, we endeavor to fall back on the judgment of the rest of the world which is perhaps better informed." The sequence is innovation, investment, uncertainty, convention. To tame uncertainty, investors have no choice but to follow a convention. This is the key point in investment decisions: nobody can know better, therefore following everybody else's judgement is the best way to invest.

As we have seen, the general framework operating in the financial markets is the projective convention. Everybody knows that the "existing state of affairs," as Keynes called it, can change, but there is no way to know how or when, so it is wise to follow what others are doing. Concretely, in the chapter 12 of General Theory, Keynes highlights three different but connected ways to look at financial markets in this context. They should be considered together in order to understand how conventions rule financial markets. The first one is beating the gun: "The actual, 
private object of the most skilled investment to-day is 'to beat the gun,' as the Americans so well express it, to outwit the crowd, and to pass the bad, or depreciating, half-crown to the other fellow" ([1936] 2018, 136). This analogy explains the attitude of the single investor vis à vis the crowd of investors. They all play the same game at the same time, but everyone is convinced they can play it better, going in and out before the others. The Schumpeterian entrepreneur (or a successful trader) is the player who actually beats the gun. The success of one (in terms of profitability) yields a bandwagoning effect, causing imitators to flock into the sector, expanding production capability, and reducing profitability. When profit expectations turn bad, the investors rush to the exit and the bubble explodes.

To explain this outcome Keynes uses another game metaphor, that of musical chairs, which "can be played with zest and enjoyment, though all the players know that ... when the music stops some of the players will find themselves unseated" (1936] 2018,136). The depiction is so apt that has been used recently also by the former CEO of Citigroup, Chuck Prince, who said: "when the music stops, in terms of liquidity, things will be complicated. But as long as the music is playing, you've got to get up and dance. We're still dancing” (Nakamoto and Wighton 2007). Although counterintuitive, it is perfectly rational to play the game even if everybody knows that somebody will be crushed by it. As Jean Tirole $(2005,278)$ put it, "herding behavior may actually be individually rational even though it is often collectively inefficient." In fact, "when the music did indeed stop Chuck Prince lost his job and Citi almost went bankrupt" (El-Erian 2017, 41). Although disruptive, this can be seen as the Nash equilibrium of real markets. ${ }^{5}$ If the two above metaphors explain how the game starts and how it ends, the last and most famous one explains the general development of financial markets:

professional investment may be likened to those newspaper competitions in which the competitors have to pick out the six prettiest faces from a hundred photographs, the prize being awarded to the competitor whose choice most nearly corresponds to the average preferences of the competitors as a whole; so that each competitor has to pick, not those faces which he himself finds prettiest, but those which he thinks likeliest to catch the fancy of the other competitors, all of whom are looking at the problem from the same point of view. It is not a case of choosing those which, to the best of one's judgment, are really the prettiest, nor even those which average opinion genuinely thinks the prettiest. We have reached the third degree where we devote our intelligences to anticipating what average opinion expects the average opinion to be. And there are some, I believe, who practise the fourth, fifth and higher degrees. (Keynes, [1936] 2018, 137)

\footnotetext{
${ }^{5}$ Thomas Palley (2013, ch. 7) explicitly proposes a model based on a Nash-Cournot equilibrium to formalize this issue; see also Thaler (2015).
} 
This is the famous BC metaphor that explains how investors compete in the real world. How do financial markets work nowadays? Managers of large institutions "operate in a world where if they have one bad quarter-worse than everyone else - they may get fired. So they ask their colleagues, what are you guys buying? They want to buy what the other guys buy, so they don't finish last" (Camerer 1997). It is worth noting that, although a leading scholar of BE, the author of this quotation is compelled to use organizational aspects (the CEO vis à vis the shareholders) to explain how the $\mathrm{BC}$ works.

Although Keynes does not compare it explicitly to a convention, the $\mathrm{BC}$ is depicted as a convention inasmuch as it is a "conventional judgment" (Dequech 2011) based on the general projective convention and "informational mimetism" (Orléan 1999, 126); moreover the BC is arbitrary, informal, self-fulfilling, and involves coordination between agents, integrating all the aspects attached to a convention (Latsis, de Larquier, and Besis 2010). Just like other conventions, the $\mathrm{BC}$ effect is "stronger during periods of intense technological or institutional change" (Angeletos, Lorenzoni, and Pavan 2010) because uncertainty is higher, hence a greater need for reassuring conventional behavior. As other conventions, the $\mathrm{BC}$ does not imply that every investor is doing exactly the same thing at the same time, which would be a farcical representation of it, but that there are prevailing market trends. This is the case in the banking business with the use of $\mathrm{VaR}$ (value at risk) as a risk management tool, used by virtually every important player in financial markets to calculate risks. A pricing model does not gain ground because it is a better predictor but mainly because market participants use it to price assets (Mackenzie and Millo 2003; Lindo 2017). In this sense, the BC entails the typical self-fulfilling mechanism of market standards. The BC in the market is reinforced by the BC in the academy. As Davis and Hands (2013) observed, "herding behavior in the economics profession and the professional investment community reduced diversification in modeling and analysis of macroeconomic performance." 


\section{ALTERNATIVES TO THE BC: BANKS VERSUS MARKETS}

For what we have explained, qualifying the $\mathrm{BC}$ as "irrational" is meaningless (Allen, Morris, and Shin 2004). Following convention is the most rational possible behavior in the financialization era, where large corporations and institutional investors have a wider role in the markets, increasing uncertainty and short-termism (Mazzucato and Penna 2015). However, there are other historical analyses that highlight a potentially different development of financial markets. In particular, we refer to the analysis that Hilferding proposed in Financial Capital, which is partially shared by Schumpeter's theory of capitalist development. ${ }^{6}$ Hilferding and other socialist thinkers tried to assess how the development of trusts and monopolies was changing the nature of capitalism. His work is an attempt to reply to Eduard Bernstein's revisionism that derived from these transformations the need to abandon the original revolutionary program of social democracy.

For our purposes, the core aspect of Hilferding's analysis is the connection between sectoral concentration and banks' stability. While British banks used to fund only the working capital, thus extending short-term lending to firms, German banks also financed investment. Long-term lending introduced new risks into banks' business models. To stabilize their profits, banks were forced to create long-term relationships with their corporate clients. To better monitor the situation of the firms, banks started to step into them, buying shares and sitting in their boards. As they funded the firms (via debt and equity) and monitored their financial flows, they assumed a de facto control; more and more, financial capital influenced their perspectives, forcing them into merging or otherwise following the best strategy for financial capital itself. Because they held shares of many firms in a sector, banks were concerned with overall sectoral profit, forcing individual firms to coordinate their strategy to maximize the sector's total profit, even if it was counter to their own interests. Besides the simple growth of the individual firm, their combination in trusts, monopolies etc., was a way to stabilize the markets. For banks and institutional investors, industrial and financial concentration - hence a more organized form of capitalism - is a way to diversify their risks. Although Hilferding's position originally was that organized capitalism remains prone to cyclical crises, after World War I, he changed his position

\footnotetext{
${ }^{6}$ We refer to Hilferding's Financial Capital (published in 1910). On this issue, see Mastromatteo (2018). As for Schumpeter's analysis, we refer mainly to Capitalism, Socialism \& Democracy (first published in 1942). See also Festré and Nasica (2009).
} 
and suggested that big conglomerates could be controlled by a democratic State for social purposes (Höpner 2004). In fact, already in his 1910 book, many observations pointed to a more stable development for financial markets. For instance, Hilferding ([1910] 1981) observed that financial speculators only intervene when they are sure of the result, so that they have a stabilizing role (ch. 8). Moreover, the concentration itself is a strong break with the past in terms of market behavior giving a more rational and stable framework to markets (ch. 20). In this sense, organized capitalism may be a way to tame the $\mathrm{BC}$ and financial instability.

More than a century after the publication of Financial Capital, it is not easy to assess whether organized capitalism is less prone to financial crises than in former times because in these decades we have seen different periods: a depression, major wars, a long upswing, crises. However, overall, historical experience suggests that organized capitalism is not enough to fend off financial crises (Minsky 1986). In fact, Hilferding's theory of capitalist development does not take into account contradictions stemming from concentration and financialization. The overwhelming role of large corporations does not erase competition or the need for innovation to resist downtrending profitability. For our purposes, the most interesting point is to detect if Hilferding's analysis diverges from Keynes's. In this sense, although Hilferding's conclusions are partially different, the historical trends he identified are basically the same we described as being behind the $\mathrm{BC}$. Both uncertainty and competition yield concentration and conventional behaviors, even if it is different from the direct control of the firms, which in Hilferding's analysis is exerted by banks (Stiglitz 1985). Hilferding explored a way to deal with these trends (direct concentration), while the $\mathrm{BC}$ is the other, therefore the basic capitalist dynamic is the same for bank-based and market-based financial systems. In modern capitalism, "financial markets facilitate the centralization of capital" (Crotty 1993), but this is true for big banks too, especially with their services as corporate lenders, therefore it is useless to present the two systems (bank-based and market-based) as they were the opposite, as economists normally do. 


\section{CONVENTIONS AND LIQUIDITY}

Immediately before exposing the BC metaphor, Keynes explains that the "fetish of liquidity" is the "more anti-social" of all the maxims of orthodox finance. We can understand now the overall meaning of this statement. Uncertainty is bad for institutional investors especially because uncertainty reduces the possibility of selling an asset. To work, financial markets need liquid assets. Therefore, the more developed the markets are (that also means the more they are ruled by institutional investors), the more they need the illusion of liquidity - the idea that assets are easy to sell because they are more or less like money, at least for the time being (i.e., as long as markets are based on the prevailing projective convention). Financialization means that the world economy is progressively based on this illusion. Investors require protection to operate in an uncertain environment. This means liquidity and hence the management of money: "What is important to emphasize here is the fact that liquidity is not an intrinsic property of the title... liquidity is the product of an institutional invention: organized financial markets" (Orléan 1999, 32, our translation; see also Dequech 2013). ${ }^{7}$ The institutional framework of the markets decides the liquidity of the traded assets (Bibow, Lewis, and Runde 2005). This "anti-social" trait of the markets is needed to let them operate. No trading strategy is conceivable without a conventional link between financial assets and money, and this also explains why financial markets cannot exist without lending of last resort.

Investors hold money (renouncing more profits) because they are uncertain about the future. When the ruling convention works, investors will renounce money because the investment they are making is supposedly liquid. This is why for Keynes interest rates have a conventional flavor: the liquidity premium is inversely correlated to the strength of the convention (Dequech 2000). Liquidity is also linked to speculation: if an asset is not easy to trade, speculating cannot work, therefore "liquidity and speculation... are the two sides of a single coin" (Orléan 1989). Stating that an asset is liquid is tantamount to stating that the convention is holding. Confidence, reputation, credibility, and economic policy stances come from this basic aspect of financial markets. Financial markets exist if they are liquid and liquidity is an illusion based on the investors' confidence that tomorrow will be like today (in emergencies, thanks to interventions

\footnotetext{
7 “Ce qu'il faut souligner ici avec force est le fait que la liquidité n'est en rien une propriété intrinsèque du titre...la liquidité est le produit d'une invention institutionelle: les marchés financiers organisés."
} 
of the central banks). As markets are progressively dominated by institutional investors, hence by conventional behaviors, the role of central banks (and, more generally, of public authorities) to assure liquidity cannot but grow, leaving laissez-faire as a convenient tale for mainstream textbooks.

\section{THE BC AND BEHAVIORAL ECONOMICS}

Since at least Maurice Allais, and more extensively with Simon, Daniel Kahneman, Amos Tversky, and Richard H. Thaler among others, mainstream finance paradigm, based on the expected utility theory, has been shown to be counterfactual. Given that the economic schools that put the $\mathrm{BC}$ at the forefront of their analysis also criticized mainstream finance theory, one could think of a natural alliance among them. However not much ever came out of it and we think for good reasons. To understand why, we can start from this very effective synthesis: "[for Keynes] the state of expectations and the preference for liquidity indicate the inexistence of automatic mechanisms capable of balancing the actual forces of the system, they point at the weakness of the rational foundations of action and call into question the stabilizing role of conventions" (Barrotta and Raffaelli 1998, 170-71). ${ }^{8}$ Cognitive biases are individual and ahistorical mechanisms. They are not linked to any particular economic system or trend. For all its differences with the Arrow-Debreu world, BE still envisages a situation where time never passes. On the contrary, Keynes analyzes historical and institutional factors as sources of conventional behavior. Convention is an outcome of history, not of brain structure. Nor can Keynes's analysis be reduced to the "imperfectionist" world, as bounded rationality does. It is true that the mind as a calculator has limited power, but the point, once again, is uncertainty due to innovation: "some information does not exist at the time of decision. Thus, fundamental uncertainty would still exist if people had superpowerful minds and computers" (Dequech 2001).

Both BE and post-Keynesian economics refuse the homo economicus framework, but in a very different way. The same cognitive biases affect a Wall Street trader and a Neolithic hunter. BE looks at individuals as consumers, or individual investors: "Real investment, which is undertaken

\footnotetext{
8 "Lo stato delle aspettative e la preferenza per la liquidità segnalano l'inesistenza di meccanismi automatici in grado di equilibrare le forze reali del sistema, indicano la labilità dei fondamenti razionali dell'agire e chiamano in causa il ruolo stabilizzante di convenzioni e precedenze non deducibili da nessun calcolo."
} 
by firms, whose decisions depend on organizational procedures and routines, is largely neglected" (Jefferson and King 2010). The fact that giant conglomerates rule financial markets is irrelevant for $\mathrm{BE}$ : the $\mathrm{CEO}$ of a giant conglomerate is no less mired in cognitive biases than a peasant of the Victorian era. Observation of social phycologists also noted that the development of organizations changes the psyche of the managers (Fung 2010). If the financial problems are caused by how the brain works, what is the point in studying how banking business models or capitalism have changed from Ricardo's time to the Keynes's and again to today? If the BC is the result of our biological evolution, we have to accept it, like we accept bipedalism and other human characteristics. As in the mainstream paradigm, the historical and institutional aspects are still useless for understanding the economy.

Without an analysis of structural changes and organizational issues, most of Keynes's insights on financial markets are lost (Lanteri and Carabelli 2011). ${ }^{9}$ The restoration of the role of the BC as a vital explanation of market dynamics cannot pass from BE "which is simply the neoclassical view with biases" (Williams 2011).

\section{POLICYMAKING IN A BC WORLD}

It is financialization that, as we explained, originates from financial and industrial concentration, the separation of ownership and control, and the mounting dominance of institutional investors (and hence of uncertainty and conventional behaviors) that explains the growing importance of the $\mathrm{BC}$ for the world economy. More and more the development of the system is based on what institutional investors think the other institutional investors are doing. This is particularly relevant for sectors dominated by giant conglomerates and institutional investors, as finance itself. This is why, for instance, mutual funds and pension funds operate particularly on herd behavior (Dass, Massa, and Patgiri 2008; Beetsma and Vos 2016) and the same happens with hedge funds, even when their managers understand that a bubble is occurring (Brunnermeier and

\footnotetext{
${ }^{9}$ Although BE paradigm is based on biological analogies, there are exceptions. For instance, Thaler (2015) points out: 'Keynes thought markets had been more 'efficient' at the beginning of the 20th century, when managers owned most of the shares in a company and knew what it was worth. As shares became more widely dispersed, 'the element of real knowledge in the valuation of investments by those who own them or contemplate purchasing them... seriously declined.' By the time of The General Theory, Keynes had concluded that markets had gone crazy." But these intuitions are in vain in a BE context.
} 
Nagel 2004). When markets are subjugated by a handful of big players, behaviors are more and more similar, thus reducing diversity and intensifying systemic risk (Haldane 2009a; Wagner 2010).

Before 2008, the growing role of herd behavior was decisive in increasing the financial system's fragility, also because it determined business models' convergence. Banks and institutional investors were getting similar. For instance, they used the same models to price financial assets, the same retailing channels and techniques (like the originate-to-distribute model), and they traded the same financial products. The BC made markets more correlated (Pozen 2010; Schiavone 2018) and banks' strategies more similar (Triana 2009). The process was helped by "market friendly" regulation, by which "the financial network has over time become progressively more complex and less diverse" (Haldane 2009b). Financialization also produced concentration in income and wealth that, in its turn, implied a bigger role for institutional investors (Toporowski 2000). For instance, stagnating wages produced an increase in household debt and a declining wage-pension rate of substitution produced an increase in assets managed by institutional investors. There are hints that the income and wealth redistribution implied by financialization is detrimental for economic growth: institutional investors and big firms' top management might rationally prefer stagnation (Stockhammer 2004). ${ }^{10}$ It is worth noting that these trends cannot be analyzed in a cognitive bias context that, by definition, is not based on trends.

Given that the $\mathrm{BC}$ is increasingly shaping market behavior, thus also affecting growth and income distribution, its importance offers a litmus test for assessing the efficacy of policymaking. Mainstream economics bases the analysis of economic policies on rational expectations, financial market efficiencies, and other counterfactual assumptions useful to justifying laissez-faire. In a BC-ruled world, a policy's effectiveness depends on how it is able to constrain it: if a policy makes it easier for the $\mathrm{BC}$ to operate, it makes world economy more fragile, i.e., it is wrong.

\footnotetext{
${ }^{10}$ Hansen proposed the idea of long-term stagnation in 1938 , but it was already part of the classical tradition (especially Stuart Mill with the stationary state [Dale 2013]). After WWII, the idea was abandoned for good. Now it is back (G30 2013; Teulings and Baldwin 2014).
} 
We can give some examples using the post-2008 crisis period. We will briefly touch on fiscal and monetary policy and then we will concentrate on financial reforms. To tame the financial crisis, states and central banks were forced to put trillions of dollars at banks' disposal. These policies depleted public finances and inflated central banks' balance sheets with an overall effect of increasing the size of financial markets in advanced as well as in many developing countries, contributing to a further financialization of the system. In a nutshell, problems have been delayed but not solved (Cavallo et al. 2018).

As for financial reforms, this is the field where more hopes were placed. Indeed, reforms were numerous and important, starting from Basel 3. Many measures went in the right direction. For instance, in the new framework, systemic risk was taken seriously and tools for macroprudential regulation have been (re)created (Galati and Moessner 2011). Banks have been forced to lower their leverage, improve their liquidity ratios, and reduce their aggressive behavior toward customers. However, the main issue of international finance, which is the role of big financial conglomerates, has not been addressed (BIS 2017, ch. 5; Crotty 2009). Banks have not been reduced in size, nor are they less interconnected or more diverse than before. In the eurozone, with its banking union, big banks are pushed to merge and become more similar because they are supervised with the same methods and procedures by the European Central Bank in a situation where their profitability is affected by adverse macroeconomic conditions (Montanaro 2016). Overall, even when the reforms go in the right direction, they are not able to change big banks' business models and behavior. This is more generally true for the effects of economic concentration (The Economist 2016). The crisis experience has shown how big banks' size matters for financial markets and the world economy. Stiff competition (and hence the BC) has played an important role in laying the groundwork for the crisis (although the causal direction is not straightforward; see Angeloni [2016] and Atkins et al. [2016]). Moreover, magnifying the role of the $\mathrm{BC}$, banking concentration has also enormously increased systemic risk. This is the most neglected aspect of the situation: reducing systemic risk without checking the $\mathrm{BC}$ is impossible. In particular, because the $\mathrm{BC}$ is a behavior stemming from the structural development of capitalism, a laissez-faire attitude (as for instance, deregulation in banking) is an attitude that allows for a bigger role for the BC in shaping finance: if authorities favor laissez faire, they also favor the BC. 
Defining the trends behind financialization as the main source of conventional behaviors allows us to assess traditional policymaking in our epoch (its scant effectiveness, in reality) and to propose viable alternatives. If we can state that policies unable to tame the $\mathrm{BC}$ are counterproductive, by the same token, viable alternatives must be able to do it: we need powerful thwarting systems to tame herd behavior (Ferri and Minsky 1991). Many of such mechanisms are already formally in place — for instance lending of last resort—but before 2008 their role was considered futile or minor and, even after 2008, the only measures that were put to work were those useful for saving big banks.

The two main points to consider in designing these mechanisms are dimension and structure. As Minsky (1992) observed talking about bank crises: "Supervision and regulation are ways to protect the government against the call of the Treasury." Now the more dominant finance and giant corporations are in the world economy, and the more the world is BC-ruled, the bigger the call of the Treasury. This explains why the State rollback, presumably begun in the ThatcherReagan era, never really materialized (see, for instance, the data in Lukasz and Smith [2015]) and, with the crisis, "public debt levels have increased dramatically. And they are set to continue rising for the foreseeable future" (Cecchetti, Mohanty, and Zampolli 2010). A strong role for the State in the economy is forced by the nature of contemporary capitalism, which is wellrepresented by the huge financial leverage of States, banks, firms, and households nowadays. It is futile to oppose big government as long as big banks and institutional investors are still there, because it is impossible to avoid the former without eliminating the latter.

If the dimension of the thwarting systems depends on the level of financialization (i.e., it should grow in line with financialization), their structure should be designed to minimize the effects of the BC. As an example we use the banking system, which is at the core of the financialization process. When financial markets are ruled by a handful of giant financial conglomerates having a similar business model, using similar risk management tools, and so on, the BC is at its zenith, so this is when we most need thwarting systems. The overall objective should be to considerably reduce systemic risk. Have post-2008 actions helped? Tougher prudential regulation is good news, but does not change much. Top management incentives or big banks' business models have not been significantly modified by reregulation (CGFS 2018). What is needed is a set of measures able to reduce the role of financial capital for decades. We give some examples. The pension system should be changed to give the main role back to the State so that pension funds- 
the main institutional investors - would conversely have a minor influence on the markets. As for big banks, whose stability can be deemed a public good, public ownership could be considered (Hein and Truger 2012); otherwise, a global cap on their size should be imposed (Mastromatteo and Esposito 2016). For the time being, as long as too-big-to-fail banks exist, financial crises will reemerge frequently.

All in all, the analysis of financialization as cause of conventions is a vital issue in assessing economic policies. The dimension of the financial sector not only dictates the dimension of the State's intervention in the economy but also its nature. In this sense, quantitative easing, with trillions spent producing tiny results (especially in terms of inflation, which is still too low), is an impressive demonstration that Keynes ([1936] 2018, 143) was right when he explained his skepticism about the strength of monetary policy alone and expected: "to see the State... taking an ever greater responsibility for directly organizing investment." This different role can reduce the $\mathrm{BC}$, changing the conventions that rule the system and giving a different trajectory to the historical development of financial markets (for an example of this different framework, see Mazzucato [2013]). From this analysis, it also follows that it is impossible to discuss the role of the State in the economy without taking into account the role of the financial system. And yet, this is what mainstream economics normally does.

\section{CONCLUSIONS: ECONOMIC THEORIES AND POLICIES IN THE REALM OF THE BC}

Macroeconomics... has succeeded." (Lucas 2003)

In this work, we have explored the nature and the role of the $\mathrm{BC}$. The most relevant point we tried to convey is that the $\mathrm{BC}$ molds capital markets and investment cycles, hence it molds the world economy because it is the inevitable behavior stemming from the growing domination of a financialized world economy by large corporations owned by institutional investors. Therefore, the more developed a country is (and the more important are their institutional investors), the more relevant conventions are for its economy. This is why the $\mathrm{BC}$ is more pervasive in the twenty-first century than in the Keynes's era. This conclusion has deep implications for the functioning of financial markets, as well as for income distribution and economic growth and for the efficacy of countercyclical policies. 
We can detect this change in the different analysis that Keynes and Minsky did of speculators vis à vis investors. Keynes clearly divided investors ("serious minded individuals") from pure speculators ("more concerned with forecasting the next shift of market sentiment than with a reasonable estimate of the future yield of capital-assets"), warning that when the latter were controlling the markets, the situation was untenable; investment was still decided by personal investors, although in a herding framework. In Minsky, the contemporary economy is represented by money manager capitalism, based on institutional investors whose herd behavior exacerbates the inevitable waves of Ponzi financing. Given that innovation is inevitable for survival, but the decision to innovate is inherently speculative due to uncertainty (Ertürk 2005), the constant changes in capitalism are based on speculation. Large corporations and professional investors take speculation and financial markets to the center stage of the economy. Fragility becomes endemic. Once again, understanding structural changes is paramount for understanding the economy.

To conclude, we would like to expand the meaning of the BC: theoretical thinking. The 2008 crisis took mainstream economics by surprise (Brancaccio and Fontana 2011; King 2016, ch. I) in such a way that most economists were put "in a state of shocked disbelief," as Alan Greenspan put it (Clark and Traenor 2008) and now they live "a grave crisis of legitimacy" (Orléan 2014). When the situation worsened after the collapse of Lehman Brothers, government and central bank actions were derived from practical considerations, not from theoretical models. This is a more general trend, because almost every important policy, for instance lending of last resort, "evolved from the practice of the market rather than from the minds of economists" (Kindleberger and Aliber 2005, 226). However, once that the panic was tamed, "business as usual" prevailed in the academy if not, fully, in banking. From the Nobel prizes downwards, mainstream paradigm has not been seriously affected. The "Minsky moment" has been just that: a moment.

Given the poor record of mainstream models in accounting for the basic trends of modern finance and capitalism, but also the impossibility of ignoring financial crises altogether, a "pluralistic open-minded approach to economics" (Palley 2013, 190) has been proposed as a sort of risk diversification: not putting all public faith in a single explanation of the world and accepting instead different paradigms and theories. It has also been suggested that economists' education would strongly gain from a more broad-based curriculum, allowing economic students 
(and scholars) to study historical and psychological issues to anchor their models to a more realistic world, especially as far as structural dynamics are concerned (De Luca 2015). In other words, crises have shown that excluding nonconventional explanations from academia and public authorities has been a mistake, leaving economists less able to explain the world. We think that a deep understanding of the financial market's dynamics in terms of conventional behavior can only derive from an analysis of the historical structural features of these markets. Neither axiomatic nor psychological models are a substitute for a thorough analysis of market development in terms of structural trends and business models of the banks and other financial operators. The necessary reconstruction work of economics and policymaking after the crisis should start from here. Once the trends behind the $\mathrm{BC}$ are acknowledged as the driving forces behind financial markets cycles, wiser choices on the future of finance and banks can be made. 


\section{REFERENCES}

Allen, F., S. Morris, and H. S. Shin. 2004. "Beauty Contests and Iterated Expectations in Asset Markets.” Cowles Foundation Discussion Paper No. 1406. New Haven, CT: Cowles Foundation.

Angeletos, G., G. Lorenzoni, and A. Pavan. 2010. "Beauty Contests and Irrational Exuberance: a Neoclassical Approach.” NBER Working Paper No. 15883. Cambridge, MA: Cowles Foundation

Angeloni, I. 2016. "Bank Competition and Bank Supervision.” Speech at CaixaBank, Barcelona, July 4.

Arthur, W. B. 1989. “Competing Technologies, Increasing Returns, and Lock-In by Historical Events." The Economic Journal 99(Mar.): 116-31.

Atkins, B., L. Li, J. Ng, and R. O. Tjomme. 2016. "Bank Competition and Financial Stability: Evidence from the Financial Crisis." Singapore Management University SAR Paper Series Vol. 2, No. 2. Singapore: Singapore Management University.

Barrotta, P., and T. Raffaelli. 1998. Epistemologia ed Economia. Il ruolo della filosofia nella storia del pensiero economico. Turin: UTE`T.

Beetsma, R., and S. Vos. 2016. "Stabilisers or amplifiers: Pension funds as a source of systemic risk." VoxEU, March 23.

Berg, N. 2015. "Behavioral Labor Economics." in M. Altman (ed.), Handbook of Contemporary Behavioral Economics: Foundations and Developments New York: Routledge.

Berle, A. A., and G. Means. 1932. The Modern Corporation and Private Property. New Brunswick: Transaction Publishers.

Bibow, J., P. Lewis, and J. Runde. 2005. "Uncertainty, Conventional Behavior, and Economic Sociology." The American Journal of Economics and Sociology 64(2): 50732.

Bikhchandani, S., D. Hirshleifer, and I. Welch. 1992. "A theory of fads, fashion, custom, and cultural change as informational cascades." Journal of Political Economy 100(5): 9921026.

BIS (Bank for International Settlements). 2017. Annual Report. Basel: Bank for International Settlements.

Boylan, T., and P. F. O’Gorman. 2013. "Post-Keynesian Economics, Rationality, and Conventions." In G. C. Harcourt and P. Kriesler (eds.), The Oxford Handbook of Post Keynesian Economics, Vol. II, Critiques and Methodology. Oxford: Oxford University Press. 
Brancaccio, E., and G. Fontana. 2011. “The Conventional Views of the Global Crisis: A Critical Assessment.” In P. A. Arestis, R. Sobreira, and J. L. Oreiro (eds.), The Financial Crisis: An Assessment of the Global Impact of the Financial Crisis. Basingstoke, UK: Palgrave Macmillan.

Brette, O., N. Lazaric, and V. Vieira da Silva. 2017. "Habit, Decision-Making, and Rationality: Comparing Thorstein Veblen and Early Herbert Simon." Journal of Economic Issues 51(3): 567-87.

Brunnermeier, M. K., and S. Nagel. 2004. "Hedge Funds and the Technology Bubble." The Journal of Finance LIX(5): 2013-40.

Burnham, J. [1941] 1972. The Managerial Revolution: What is Happening in the World. Westport, CT: Greenwood Press.

Camerer, C. 1997. “Taxi Drivers and Beauty Contests.” Engineering \& Science 1: 10-19.

Cavallo, M., M. Del Negro, W. S. Frame, J. Grasing, B. A. Malin, and C. Rosa. 2018. "Fiscal Implications of the Federal Reserve's Balance Sheet Normalization." Federal Reserve Bank of New York Staff Report No. 833. New York: Federal Reserve Bank of New York.

Cecchetti, S., M. Mohanty, and F. Zampolli. 2010. "The Future of Public Debt: Prospects and Implications.” BIS Working Paper No. 300. Basel: Bank for International Settlements.

Cespa, G. and X. Vives. 2015. "The Beauty Contest and Short-Term Trading." The Journal of Finance 70(5): 2099-154.

CGFS (Committee on the Global Financial System). 2018 "Structural changes in banking after the crisis." CGFS Paper No. 60. Basel: Committee on the Global Financial System.

Chamley, C. P. 2002. Rational Herds: Economic Models of Social Learning. Cambridge, UK: Cambridge University Press.

Chandler, A. D. J. 1977. The Visible Hand: The Managerial Revolution in American Business. Cambridge, MA: Harvard University Press.

Clark, A., and J. Traenor. 2008. "Greenspan-I was wrong about the economy. Sort of." The Guardian, October 24.

Crotty, J. R. 1990. “Owner-Manager Conflict and Financial Theories of Investment Instability: A Critical Assessment of Keynes, Tobin, and Minsky." Journal of Post Keynesian Economics 12(4): 51-542.

—. 1993. "Rethinking Marxian Investment Theory: Keynes-Minsky Instability, Competitive Regime Shifts, and Coerced Investment." Review of Radical Political Economics 25(1): 1-26. 
- 2009. "Structural causes of the global financial crisis: a critical assessment of the "new financial architecture." Cambridge Journal of Economics 33(4): 563-80.

Dale, G. 2013. "Critiques of Growth in Classical Political Economy: Mill's Stationary State and a Marxian Response." New Political Economy 18(3): 431-57.

Dass, N., M. Massa, and R. Patgiri. 2008. "Mutual Funds and Bubbles: The Surprising Role of Contractual Incentives.” Review of Financial Studies 21(1): 51-99.

Davidson, P. 1991. "Is Probability Theory Relevant for Uncertainty? A Post Keynesian Perspective.” Journal of Economic Perspectives 5(1): 129-43.

Davies, R., A. G. Haldane, N. Mette, and S. Pezzini. 2014. "Measuring the costs of shorttermism.” Journal of Financial Stability 12(C): 16-25.

Davis, J. B., and W. Hands. 2013. "Introduction: Methodology, systemic risk, and the economics profession." Journal of Economic Methodology 20(1): 1-5.

De Luca, G. 2015. "Le crisi finanziarie dalla Tulipanomania alla bolla del 1987: lezioni dalla storia." Italiano LinguaDue 2.

Dequech, D. 1999. "Expectations and Confidence Under Uncertainty." Journal of Post Keynesian Economics 21(3): 415-30.

- 2000. “Asset Choice, Liquidity Preference, and Rationality Under Uncertainty." Journal of Economic Issues 34(1): 159-76.

- 2001. "Bounded Rationality, Institutions, and Uncertainty." Journal of Economic Issues 35(4): 911-29.

- 2003. "Conventional and unconventional behavior under uncertainty." Journal of Post Keynesian Economics 26(1): 145-68.

- 2006. "Toward an Alternative to the Game-Theoretic Concept of Conventions." Proceedings of the 34th Brazilian Economics Meeting, Salvador de Bahia, December 58.

- 2011. "Financial Conventions in Keynes's Theory: The stock Exchange." Journal of Post Keynesian Economics 33(3): 469-90.

- 2013. "Is money a convention and/or a creature of the state? The convention of acceptability, the state, contracts, and taxes." Journal of Post Keynesian Economics 36 (2): 251-74.

Dunn, S. P. 2003. "Keynes and transformation.” In J. Runde and S. Mizuhara (eds.), The Philosophy of Keynes's Economics. London: Routledge.

European Central Bank. 2014. “The ECB's Forward Guidance.” Monthly Bulletin, April. Frankfurt: European Central Bank. 
El-Erian, M. A. 2017. The Only Game in Town. New Haven, CT: Yale University Press.

Elster, J. 1983. Explaining Technical Change: a Case Study in the Philosophy of Science. Cambridge, MA: Cambridge University Press.

Ertürk, K. 2005. “Macroeconomics of Speculation.” Levy Economics Institute of Bard College Working Paper No. 424. Annandale-on-Hudson, NY: Levy Economics Institute of Bard College.

Farmer, R. E. A. 2009. "Confidence, Crashes and Animal Spirits.” NBER Working Paper No. 14846. Cambridge, MA: National Bureau of Economic Research.

- 2010. How the Economy Works. Confidence, Crashes, and Self-Fulfilling Prophecies. Oxford: Oxford University Press.

Favereau, O. 2013. "Keynes After the Economics of Conventions.” Evolutionary and Institutional Economics Review 10(2): 179-95.

Ferri, P., and H. P. Minsky. 1991. "Market Processes and Thwarting Systems." Levy Institute Working Paper No. 64, Annandale-on-Hudson, NY: Levy Economics Institute of Bard College.

Festré, A., and E. Nasica. 2009. "Schumpeter on money, banking and finance: An institutionalist perspective." European Journal of the History of Economic Thought 16(2): 325-56.

Fung, M. V. 2010. "Comments on 'Can Post Keynesians make better use of behavioral economics?"' Journal of Post Keynesian Economics 33(2): 235-50.

Galati, G., and R. Moessner. 2011. "Macroprudential policy-a literature review.” BIS Working Paper No. 337. Basel: Bank for International Settlements.

Galbraith, J. K. 1967. The New Industrial State. Princeton, NJ: Princeton University Press.

Greenspan, A. 2008. "The Financial Crisis and the Role of Federal Regulators." Committee on Oversight and Government Reform Hearings, Washington, DC, October 23.

G30 Working Group. 2013. "Long-Term Finance and Economic Growth.” Special Report. Washington, DC: G30 Working Group.

Haldane, A. G. 2009a. "Why Banks Failed the Stress Test." BIS Review No. 18. Basel: Bank for International Settlements.

- 2009b. "Rethinking the financial network." Speech at the Financial Student Association, April 28, Amsterdam.

Hein, E., and A. Truger. 2012. "Finance-dominated capitalism in crisis - the case for a global Keynesian New Deal.” Journal of Post Keynesian Economics 35(2): 187-213. 
Hilferding, R. [1910] 1981. Das Finanzkapital: Eine Studie über die jüngste Entwicklung des Kapitalismus. Wien, Wiener Volksbuchhandlung (English translation: Finance Capital. A Study of the Latest Phase of Capitalist Development. London: Routledge and Keegan Paul).

Höpner, M. 2004. "Sozialdemokratie, Gewerkschaften und organisierter Kapitalismus, 18802002.” MPIfG Discussion Paper No. 04/10. Cologne: Max Planck Institute for the Study of Societies (MPIfG).

Jefferson, T., and J. E. King. 2010. "Can Post Keynesians make better use of behavioral economics?” Journal of Post Keynesian Economics 33(2): 211-34.

Jensen, M. C., and W. H. Meckling. 1976. "Theory of the Firm: Managerial Behavior, Agency Costs and Ownership Structure.” Journal of Financial Economics 3(4): 305-60.

Katz, M., and C. Shapiro. 1985. "Network Externalities, Competition and Compatibility" American Economic Review LXXV: 424-40.

Keynes, J. M. 1921. A Treatise on Probability. London: MacMillan. [1926] 2012. “The end of laissez-faire.” In D. Moggridge (ed.), The Collected Writings of John Maynard Keynes, Vol. 9, Cambridge, UK: Cambridge University Press. [1936] 2018. The General Theory of Employment, Interest and Money. London: Palgrave MacMillan.

1937. "The General Theory of Employment" Quarterly Journal of Economics 52(2): 209-23.

Kindleberger, C. P., and R. Z. Aliber. 2005. Manias, Panics and Crashes. London: Palgrave Macmillan.

King, M. A. 2016. The End of Alchemy. Money, Banking and the Future of Global Economy. London: W. W. Norton.

Kline, S. J., and N. Rosenberg. 2009. “An Overview of Innovation.” In S. J. Kline and N. Rosenberg (eds.), Studies on Science and the Innovation Process. Singapore: World Scientific Publishing Co. Pte.

Kurz, M. 1994. "On the Structure and Diversity of Rational Beliefs." Economic Theory 4(6): 877-900.

- 2008. "Beauty Contests Under Private Information and Diverse Beliefs: How different?" Journal of Mathematical Economics 44(7-8): 762-84.

Kurz, M., and M. Motolese. 2010. “The Role of Diverse Beliefs in Asset Pricing and Equity Premia.” Mimeo. 
Lanteri, A., and A. Carabelli. 2011. "Beauty contested: how much of Keynes's remains in behavioural economics' beauty contests?" European Journal of the History of Economic Thought 18: 269-85.

Latsis, J., G. de Larquier, and F. Besis. 2010. "Are conventions solutions to uncertainty? Contrasting visions of social coordination." Journal of Post Keynesian Economics 32(4): 535-58.

Lawson, T. 2003. “Keynes's realist orientation.” In J. Runde and S. Mizuhara (eds.), The Philosophy of Keynes's Economics. London: Routledge.

Lindo, D. 2017. "Why derivatives need models: the political economy of derivative valuation models." Cambridge Journal of Economics 42(4): 987-1008.

Lucas, R. 2003. “Macroeconomic Priorities.” American Economic Review 93(1): 1-14.

Lukasz, R., and T. D. Smith. 2015. "Secular drivers of the global real interest rate." Bank of England Working Paper No. 571. London: Bank of England.

MacKenzie, D., and Y. Millo. 2003. "Constructing a Market, Performing Theory: The Historical Sociology of a Financial Derivatives Exchange." American Journal of Sociology 109(1): $107-45$.

Marris, R. 1964. The Economic Theory of Managerial Capitalism. London: Palgrave Macmillan.

-1998. Managerial Capitalism in Retrospect. London: Palgrave Macmillan.

Marris, R., and D. Mueller. 1980. "The Corporation, Competition and the Invisible Hand." Journal of Economic Literature XVIII: 32-63.

Mastromatteo, G. 2018. "Financial Capital and Banks in Hilferding and Sraffa: Lessons for Today." The European Journal of History of Economic Thought 26(1): 51-80.

Mastromatteo, G., and L. Esposito. 2016. "Minsky at Basel: A Global Cap to Build an Effective Post crisis Banking Supervision Framework.” Levy Institute Working Paper No. 875. Annandale-on-Hudson, NY: Levy Economics Institute of Bard College.

Mazzucato, M. 2013. The Entrepreneurial State: Debunking Public vs. Private Sector Myths. London: Anthem Press.

Mazzucato, M., and C. C. R. Penna. 2015. "Beyond market failures: The market creating and shaping roles of state investment banks." Levy Institute Working Paper No. 831. Annandale-on-Hudson, NY: Levy Economics Institute of Bard College.

Meeks, G. T. 2003. "Keynes on the rationality of decision procedures under uncertainty: the investment decision." In J. Runde and S. Mizuhara (eds.), The Philosophy of Keynes's Economics. London: Routledge.

Minsky, H. P. 1986. Stabilizing an Unstable Economy. New Haven, CT: Yale University Press. 
_ 1992. "Financial Instability and APT Bank Supervision." Hyman P. Minsky Archive, Paper 470. Available at: https://digitalcommons.bard.edu/hm_archive/470

Mizuhara, S. 2003. "Keynesian convention: a textual note." In J. Runde and S. Mizuhara (eds.), The Philosophy of Keynes's Economics. London: Routledge.

Montanaro, E. 2016. "The process toward the centralization of the European financial supervisory architecture: the case of the banking union." PSL Quarterly Review 69(277): $135-72$.

Nakamoto, M. and D. Wighton. 2007. "Citigroup chief stays bullish on buy-outs." Financial Times, July 9.

OECD (Organisation for Economic Co-operation and Development). 2017. OECD Institutional Investors Statistics. Paris: OECD Publishing.

Orléan, A. 1989. "Mimetic Contagion and Speculative Bubbles." Theory and Decision 27(1-2): 63-92.

—. 1999. Le pouvoir de la finance. Paris: Odile Jacob.

—2004. L'économie des conventions: definitions et resultats. Préface à la réédition de Analyse économique des conventions. Paris: Presses Universitaires de France.

—. 2014. The Empire of Value. A New Foundation for Economics. Boston: MIT Press.

Palley, T. 2013. Financialization. The Economics of Finance Capital Domination. London: Palgrave Macmillan.

Pasinetti, L. 2009. “Introduzione.” Convegno Internazionale dell'Accademia dei Lincei "Gli economisti postkeynesiani di Cambridge e l'Italia." Speech at the Accademia dei Lincei, Rome, March 11.

Poincaré, J. H. 1905. Science and Hypothesis. New York: The Walter Scott Publishing Co.

Pozen, R. 2010. Too Big to Save? How to fix the U.S. Financial System. Hoboken, NJ: Wiley.

Roncaglia, A. 2009. "Keynes and probability: An assessment." The European Journal of the History of Economic Thought 16(3): 489-510.

Rossi, M. 1996. "L'intermediazione finanziaria nella nuova teoria keynesiana." In C. Gnesutta (ed.), Incertezza, moneta, aspettative, equilibrio. Saggi per Fausto Vicarelli. Bologna: Il Mulino.

Scharfstein, D. S., and J. C. Stein. 1990. "Herd Behavior and Investment." American Economic Review 80(3): 465-79. 
Schiavone, A. 2018. "Come stimare l'effetto di contagio attraverso il canale degli investimenti di portafoglio utilizzando un approccio di network." QEF Banca d'Italia No. 429. Rome: Banca d'Italia.

Schumpeter, J. A. S. 1942. Capitalism, Socialism and Democracy. New York: Harper \& Brothers.

Simon, H. A. 1947. Administrative Behavior: A Study of Decision-Making Processes in Administrative Organization. London: Macmillan.

SEP (Stanford Encyclopedia of Philosophy). 2015. "Moore's Moral Philosophy.” Stanford, CA: Center for the Study of Language and Information.

Stenfors, A. 2014. "LIBOR as a Keynesian Beauty Contest: A Process of Endogenous Deception." Review of Political Economy 26(3): 392-407.

Stiglitz, J. E. 1985. “Credit Markets and the Control of Capital.” Journal of Money, Credit, and Banking 17(2): 133-52.

Stockhammer, E. 2004. "Financialisation and the slowdown of accumulation." Cambridge Journal of Economics 28(5): 719-41.

Teulings, C., and R. Baldwin (eds). 2014. Secular Stagnation: Facts, Causes and Cures. London: CEPR Press.

Thaler, R. 2015. “Keynes’s ‘beauty contest.”' Financial Times, July 10.

The Economist. 2016. “A giant problem.” September 17.

Tirole, J. 1988. The Theory of Industrial Organization. Boston: MIT Press.

- 2005. The Theory of Corporate Finance. Princeton, NJ: Princeton University Press.

Toporowski, J. 2000. The end of finance: The theory of capital market inflation, financial derivatives and pension fund capitalism. London: Routledge.

Triana, P. 2009. Lecturing Birds on Flying. Can Mathematical Theories Destroy the Financial Markets? Hoboken, NJ: Wiley.

UNCTAD (United Nations Conference on Trade and Development). 2017. "The 'New' Digital Economy and Development.” Technical Note No. 8. New York: UNCTAD.

Wagner, W. 2010. "In the Quest of Systemic Externalities: A Review of the Literature." CESifo Economic Studies 56(1).

Williams, E. E. 2011. "In the land of the blind the one-eyed are king: how financial economics contributed to the collapse of 2008-2009." Journal of Post Keynesian Economics 34(1): $3-24$. 
Whalen, C. J. 2017. "Understanding Financialization: Standing on the Shoulders of Minsky." Levy Institute Working Paper No. 892. Annandale-on-Hudson, NY: Levy Economics Institute of Bard College.

Young, H. P. 1996. “The Economics of Convention.” Journal of Economic Perspectives 10(2): $105-22$. 